\title{
Wayang dan Seni Pertunjukan: Kajian Sejarah Perkembangan Seni Wayang di Tanah Jawa sebagai Seni Pertunjukan dan Dakwah
}

\author{
Bayu Anggoro \\ Universitas Sebelas Maret, Surakarta \\ bayuanggoro6969@gmail.com
}

\begin{abstract}
The life of Javanese society which is full of tradition began to change when Islam entered the Java island.The Islamic bearers and disseminators were searching for gaps between animism and dynamism. Various channels and attempts were done to incorporate Islamic teachings into Java. Javanese was loaded with mystical life embodied in ceremonial traditions of ancestor spirits. The beginning of Wayang closely related with a ceremonial tradition of ancestor spirit called Hyang.To honor and praise it to always be protected is done in various ways, such as with a shadows show. This shadows show of the ancestors' spirits continued to be a tradition in agrarian society.Art as one of the elements of culture, is a form of human activity in a particular purpose. Therefore, art communicates the value that underlies human action. One of the forms of art is the performance of wayang kulit. Cultural form of Wayang is symbolized by the character of Punakawan. While the main core of culture is creativity, taste and intention, how the origins of Wayang Kulit arts, the notion of Wayang Kulit, the history of the function and role of the Wayang Kulit in the Walisongo and present times.In education, Wayang teaches about the value of ancestors that must be preserved to this day.
\end{abstract}

Keywords: Wayang, performing arts, Wayang history, education.

\begin{abstract}
Abstrak
Kehidupan masyarakat Jawa yang penuh dengan tradisi mulai mengalami perubahan ketika Islam memasuki pulau Jawa. Para pembawa dan penyebar Islam mencari celah di antara kekuatan animisme dan dinamisme, berbagai saluran dan upaya dilakukan untuk memasukan ajaran Islam masuk ke Jawa, penduduk Jawa sarat dengan kehidupan mistik yang diwujudkan dalam upacara-upacara tradisi pemujaan roh nenek moyang. awal timbulnya wayang erat hubungannya dengan pemujaan roh leluhur yang disebut hyang. Untuk menghormati dan memujanya agar selalu dilindungi dilakukan berbagai cara, salah satu dengan pertunjukan bayang-bayang. Pertunjukan bayang-bayang roh leluhur ini terus dilakukan sehingga menjadi suatu tradisi dalam masyarakat agraris. Kesenian sebagai salah satu unsur kebudayaan, merupakan bentuk aktivitas manusia dalam tujuan tertentu, oleh karena itu seni mengkomunikasikan nilai yang mendasari tindakan manusia. Salah satu bentuk kesenian itu adalah pergelaran wayang kulit. Dimana bentuk kebudayaan dari wayang dilambangkan dengan tokoh punakawan. Sedangkan inti pokok dari kebudayaan adalah cipta, rasa dan karsa. bagaimana asal usul kesenian wayang kulit, Pengertian tentang wayang kulit, sejarah fungsi dan peranan Wayang kulit pada masa Walisongo dan masa sekarang.
\end{abstract}

Kata Kunci: Wayang, seni pertunjukan, sejarah Wayang, pendidikan. 


\section{PENDAHULUAN}

Kehidupan masyarakat Jawa yang penuh dengan tradisi mulai mengalami perubahan ketika Islam memasuki pulau Jawa. Para pembawa dan penyebar Islam mencari celah-celah di antara kekuatan animisme dan dinamisme, berbagai saluran dan upaya dilakukan untuk memesukan ajaran Islam masuk ke Jawa, penduduk Jawa sarat dengan kehidupan mistik yang diwujudkan dalam upacara-upacara tradisi pemujaan roh nenek moyang (Marina Puspitasari, 2008:1)

Upacara tradisional merupakan bagian kegiatan sosial yang melibatkan warga masyarakat dalam mencapai tujuaan dan keselamatan bersama, dan merupakan salah satu perwujudan dari nilai budaya mayarakat pendukungnya. Pada waktu agama Hindu dan Budha merembes memasuki kehidupan masyarakat Jawa, tradisi asli masyarakat Jawa tidak dilenyapkan atau dihilangkan, tatapi sebaliknya kehadiran agama Hindu-Budha melebur menjadi satu kedalam kebudayaan asli, sehingga unsur dari luar telah menjadi milik masyarakat Jawa. Bahkan pada zaman Hindu-Budha inilah kehidupan mistik masyarakat Jawa mengalami puncaknya.

Menurut Sunarto (1979:29), pada awal timbulnya wayang erat hubungannya dengan pemujaan roh leluhur yang disebut hyang. Untuk memnghormati dan memujanya agar selalu dilindungi dilakukan berbagai cara, salah satu dengan pertunjukan bayang-bayang. Pertunjukan bayangbayang roh leluhur ini terus dilakukan sehingga menjadi suatu tradisi dalam masyarakat agraris.

Wayang adalah salah satu jenis kebudayaan Jawa yang telah ada dan dikenal oleh masyarakat Jawa sejak \pm 1500 tahun yang lalu. Kebudayaan Hindu masuk ke Jawa membawa pengaruh pada pertunjukan bayang-bayang, yang kemudian dikenal dengan pertunjukan wayang. Dalam penyebaran agama Hindu di pulau Jawa, para Brahmana menggunakan kitab Mahabarata dan Ramayan selain kitab Weda sehingga kedua kitab ini dikenal di masyarakat Jawa. Cerita wayang semula menceritakan petualangan dan kepahlawanan nenek moyang kemudian beralih ke cerita Mahabarata dan Ramayana. Pada zaman Hindu ini seni pewayangan semakin populer terutama dengan disalinya ke dalam bahasa Jawa Kuno. (Marina Puspitasari,2008:4)

Menurut Koentjaraningrat, unsur kebudayaan jawa, yang diciptakan dalam rangka mencapai kesejahteraan, keselamatan dan kebahagiaan hidup lahir dan batin:

\section{1) Kepercayaan}

Kepercayaan merupakan suatu keyakinan yang diyakini oleh seseorang dalam hubungannya terkait dengan tuhan-Nya. Kepercayaan bagi nenek moyang Jawa meliputi: (a) kepercayaan terhadap kosmologi dan kosmogani tentang penciptaan alam dunia beserta susunannya.(b) kepercayaan terhadap 
dewa-dewa sebagai pelindungnya. (c) kepercayaan terhadap mahluk gaib. (d) kepercayaan kepada kekuatan dan kesaktian.

2) Tradisi

Tradisi atau adat istiadat adalah suatu budaya yang pernah dilakukan oleh generasi sebelumnya, dengan mengadakan serangkaian upacara-upacara, antara lain: a) upacara "paruwatan" yaitu upacara yang dimaksudkan untuk membersihkan seseorang dari kotoran yang masih melekat: (b) upacara ruwatan, merupakan upacara yang lazim diperingati oleh masyarakat Jawa yang dilaksanakan pada tiap bulan Ruwah: (c) upacara pernikahan, pelaksanaan upacara pernikahan ini biasanya disesuaikan dengan status sosialnya, tujuan dari upacara ini adalah mengungkapkan rasa syukur dan memanjatkan doa agar kedua mempelai dapat menjalani hidup.

Kesenian sebagai salah satu unsur kebudayaan, merupakan bentuk aktivitas manusia dalam tujuan tertentu, oleh karena itu seni budaya mengkomunikasikan nilai-nilai yang mendasari tindakan manusia. Salah satu bentuk kesenian itu adalah pergelaran wayang kulit. Dimana bentuk kebudayaan dari wayang dilambangkan dengan tokoh punakawan. Sedangkan inti pokok dari kebudayaan adalah cipta,rasa dan karsa.

\section{HASIL DAN PEMBAHASAN}

\section{Asal Usul Wayang Kulit}

Wayang merupakan sebuah warisan budaya nenek moyang yang diperkirakan telah ada sejak \pm 1500 tahun SM. Wayang sebagai salah satu jenis pertunjukan sering diartikan sebagai bayangan yang tidak jelas atau samarsamar, bergerak kesana kemari. Bayangan yang samar tersebut diartikan sebagai gambaran perwatakan manusia. Di Indonesia terutama dipulau jawa terdapat ratusan jenis wayang yang dapat digolongkan menurut cerita yang dibawakan, cara pementasan wayang, dan bahan yang digunakan untuk membuat wayang. Sekitar separuh lebih dari jumlah wayang tersebut sekarang sudah tidak dipertunjukan lagi, bahkan diantaranya sudah punah. Diantara pertunjukan wayang yang paling utama dan masih terdapat hingga sekarang adalah wayang kulit di Jawa Tenggah. Kepopuleran wayang kulit dikarenakan padat dengan nilai filosofis, pedagogis, historis, dan simbolis.

Dalam perkembangannya dari zaman ke zaman, wayang telah mengalami perubahan sesuai dengan perkembangan kebudayaan masyarakat pendukungnya, baik dalam bentuk atribut, fungsi maupun peranannya. Wayang telah melewati berbagai peristiwa sejarah dari generasi ke generasi. Budaya pewayangan telah melekat dan menjadi bagian hidup dari bangsa Indonesia, khususnya masyarakat Jawa. Usia yang demikian panjang dan kenyataan bahwa sampai sekarang masih banyak orang yang menggemari wayang menunjukan betapa tinggi nilai dan berartinya wayang bagi kehidupan masyarakat. 
Ada beberapa pendapat mengenai wayang. Wayang berasal dari bahasa Jawa Kuna dari kata wod dan yang, artinya gerakan yang berulang ulang dan tidak tetap, dengan arti kata itu maka dapat dikatakan bahwa wayang berarti wujud bayangan yang samar-samar selalu bergerak-gerak dengan tempat yang tidak tetap. (Marina Puspitasari,2008:32)

Bastomi Suwaji $(1993 ; 43)$ berpendapat bahwa wayang adalah potret kehidupan berisi sanepa, piwulang dan pituduh. Wayang berisi kebiasaan hidup, tingkah laku manusia yang dialami sejak lahir, hidup, meninggal yang semuannya itu merupakan proses alamiah. Dalam proses ini manusia senantiasa mengupayakan keseimbangan dengan alam, sesama manusia, dan tuhan sebagai sang pencipta.

Kata wayang dapat diartikan sebagai gambar atau tiruan manusia yang terbuat dari kulit, kayu, dan sebagainya untuk mempertunjukan sesuatu lakon atau cerita. Lakon tersebut diceritakan oleh seorang yang disebut dalang. Arti lain dari kata wayang adalah ayang-ayang(bayangan), karena yang dilihat adalah bayangan dalam kelir. Disamping itu ada yang mengartikan bayangan ialah angan-angan. Bentuk apa saja pada wayang disesuaikan dengan perilaku tokoh yang dibayangkan dalam angan-angan misalnya orang baik, digambarkan badanya kurus, mata tajam, dan seterusnya. Sementara orang yang jahat bentuk mulutnya lebar, mukanya lebar, dan seterusnya, sedangkan kulit menunjuk pada bahan yang digunakan (Marina Pustpitasri, 2008:33)

\section{Fungsi Wayang dalam Masyarakat}

Dalam hal ini Manusia setelah melalui tingkatan hidup estetis, dan etis, manusia akan sampai pada tingkatan ketiga, yaitu religius. Pada tingkatan ini, manusia telah terikat dengan Tuhan atau menerima ikatan-ikatannya. Dalam sejarah manusia dijumpai fenomena yang disebut religi. Asal kata religi tidak jelas, ada yang mengatakan bahwa itu berhungan dengan kata ragare, bahasa latin yang berarti mengikat sehingga religius berarti ikatan. Dalam religi, manusia terikat dengan aturan-aturan Tuhan, manusia yang beragama dengan baik, selalu menjahui larangan-Nya, dan melaksanakan segala perintah-Nya. Dengan ungkapan lain, religi adalah penyerahan diri kepada Tuhan, dengan keyakinan bahwa manusia itu tergantung kepada Tuhan. Tuhan diyaikini akan memberikan keselamatan bagi manusia. Untuk memeproleh keselamatan maka manusia berserah diri kepadanya.

Sejarah perkembangan religi masyarakat Jawa telah dimulai sejak zaman prasejarah. Pada waktu itu nenek moyang sudah beranggapan bahwa semua benda yang ada disekelilingnya bernyawa, dan semua yang bergerak dianggap hidup, mempunyai kekuatan gaib, roh yang berwatak baik maupun jahat. Pada zaman prasejarah pertunjukan wayang berfungsi sebagai magis-mitos-religius.

Dalam kepercayaan animisme dan dinamisme, roh orang yang sudah meninggal dianggap lebih kuat atau sakti dan berkuasa dibandingkan ketika masih hidup. Mempercayai bahwa roh orang sudah meninggalmasih berada di lengkungan sekitar, misalnya dipohon-pohon besar, gunung-gunung, bukit dan 
benda lainnya. Kehadiran roh orang yang sudah meninggal diharapakan dapat memberikan pertolongan dan bantuan serta berkah kepada orang yang masih hidup. Berdasarkan pemikiran itu dengan sendirinya orang samapi pada usaha untuk mendatangkan roh nenek moyang ke dalam rumah, halaman atau tempat yang dianggap keramat. Dengan perantara orang sakti, roh nenek moyang didatangkan dengan diiringi nyanyian, pujian, dan sesaji, seperti: makanan, minuman dan buah-buahan serta wangi-wangian yang digemarinya ketika masih hidup di dunia. Sekalipun hanya untuk waktu yang sementara, namun kesempatan untuk dapat berhubungan langsung dengan roh tersebut sangat penting. Dalam kesempatan ini, mereka yang masih hidup dapat menghortmati roh leluhur, dengan cara ini keluarga dan keturunananya merasa terjamin kelangsungan hidupnya, nasib baik, kebahaigaiaan, dan kemakmuran.

Harapan-harapan yang kemudian mendorong nenek moyang menghasilkan pembuatan bayangan, sehingga orang dapat membayangkan roh orang yang sudah meninggal. Gambar atau lukisan bentuk dari roh yang dibayangkan bukanlah berwujud gambar realitas dari nenek moyang, tetapi berwujud gambar bayangan remang-remang atau semu. Inspirasi bentuk wayang yang dipergunakan untuk pentas bayangan didapat dari bentuk bayangan manusia. Gambar bayangan tersebut diilhami oleh bayangan yang dilihat setiap hari diwaktu pagi. Itulah sebabnya gambar yang dihasilkan mempunyai kaki dan tangan panjang. Pada mulanya tidak sengaja dipasang tabir atau selembar kain untuk membuat bayang-bayang yang kemudian tabir tersebut menjadi perlengkapan wajib dalam pementasan wayang.

Upacara memanggil roh nenek moyang dilakukan pada malam hari, saat roh tersebut melayang-layang sedang mengembara. Tempat yang dipilih untuk mengadakan pertunjukan bayang-bayang adalah ditempat khusus. Di tempat itu disediakan tempat pemujaan seperti dolmen, menhir, dan tahta batu sebagai tempat berkumpul dan tempat duduk roh atau hyang yang datang. Pertunjukan bayang-bayang tersebut diawali dengan cerita mitos kuno tradisional yang berisikan cerita atau kejadian tentang bumi, langit, nenek moyang manusia, dewa dan upacara-upacara yang berhubungan dengan kepercayaan. Diceritakan pila tentang kebesaran dan kepahlawanan nenek moyang serta mengharapkan berkah untuk keselamatan seamanya. Pada zaman ini kepustakaan wayang belum ditulis. Cerita tersebut dituturkan secara lisan dari generasi ke generasi berikutnya, yang setiap kurun waktu cerita tersebut diubah dan ditambah menurut selera dan situasi zamannya.

Pertunujkan wayang pada zaman kerajaan mataram 1 tidak hanya berfungsi magis-religius, tetapi juga sebagai alat pendidikan dan komunikasi. Cerita diambil dari kitab Mahabarata dan Ramayana yang sudah diberi sifat lokal dan bercampur mitos kuno tradisional. Pahlawan-pahlawan dari kedua kitab tersebut menjadi pahlawan dan deaw bagi masyarakat Jawa. Hasil karya lainnya yang sangat erat hubungannya dengan perkembangan pertunjukan wayang, yaitu mulai dipahatnya relief cerita Ramayana dengan lengkap dan 
bagus dalam dinding candi Roro Jonggrang di Prambanan pada tahun $\pm 782-872$ Masehi.

Di Jawa Timur, wayang digambar diatas kain dan sudah diberi warna. Jumlah wayang yang cukup banyak dan sudah dilengkapi dengan kelir, saron, kemanak, suluk, dan sinden. Hal ini dapat diketahui dengan syair Warta Sancaya bait ke 93. Pada tahun 1361 dibuat wayang beber dari kertas yang sudah diringi gamelan slendro. Pertunjukan wayang pada zaman ini dilakukan pada malam hari, dirumah atau tempat yang dianggap keramat oleh orang sakti, kepala keluarga, atau kadang-kadang oleh Raja sendiri. Di Jawa Timur seni pewayangan masih tetap berfungsi untuk kegiatan ritual dan menjadi sarana untuk mendukung wibawa kekuasaan raja

Pada zaman kerajaan Demak pertunjukan wayang digunakan sebagai media dakwah penyebaran agama Islam, alat pendidikan, dan hiburan. Cerita wayang diambil dari cerita babad, yaitu antara wiracarita Ramayana atau Mahabarata versi Indonesia dengan ccerita yang berisi Islam. Wayang pada zaman ini sudah berbentuk pipih menyerupai bentuk wayang yang terlihat sekarang. Pertunjukan wayang dipimpin oleh seorang dalang yang sekaligus seorang tokoh agama.

\section{Wayang kulit Sebagai Media Dakwah Sunan Kalijaga}

Sunan Kalijaga merukan salah satu wliyullah yang termasuk dalam walisongo. Kedudukannya sebagai seorang wali dikukuhkan dahadapan sunan Giri yang dianggap sebagai ketua para wali dijawa. Sebagai tanda kewalian. Sunan Kalijaga bergelar sunan seperli wali lainnya. Kata sunan berasal dari bahasa Arab yang merupakan kata jamak dari sunnat yang berarti tingkah laku, adat kebiasaan. Adapun tingkah laku yang dimaksud adalah yang serba baik, sopan santun,, berbudi luhur, hidup penuh dengan kebajikan sesuai tuntutan agama Islam. Oleh karena itu seorang sunan akan senantiasa berperilaku penuh kebajikan mengajak kearah dan melarang perbuatan mungkar.

Perenan Sunan Kalijaga dalam berdakwah tampak dalam berbagai kegiatan baik agama secara langsung, bidang pemerintahan, maupun dalam kegiatan seni budaya, yang berkaitan dengan agama Sunan mendirikan masjida Agung Demak bersama Sunan yang lainnya. Selain sebagai sarana ibadah juga sebagai sarana Dakwah. Masjid ini dibangun pada tahun 1479 Masehi.

Dalam seni budaya Sunan Kalijaga ahli dalam menciptakan seni pakaian, seni suara, seni ukir, seni gamelan termasuk juga seni wayang. Bahkan terhadap kesenian wayang ini Sunan Kalijaga dipandang sebagai tokoh yang menghasilkan kreasi baru. Wayang kulit ini merupakan pengembangan baru dari wayang beber yang memang sudah ada sejak lama sejak zaman airlangga. Selain itu, Sunan Kalijaga juga mengarang cerita-cerita baru untuk memainkan pertunjukan wayang. 


\section{Latar belakang Sunan Kalijaga berdakwah dengan Wayang Kulit}

Islam tumbuh di Jawa bersamaan dengan jatuhnya kerajaan Majapahit sebagai pusat agama Hindu-Budha yang ditandai dengan berdirinya kerajaan Islam di Demak pada tahun 1518 Masehi. Menurut para ahli berdirinya kerajaan Demak merupakan transisi antara kerajaan di daerah pedalaman berpindah kedaerah pesisiran dan beralihnya agama Hindu-Budha ke agama Islam.

Hal menarik yang patut diperhatikan dengan masuknya Islam ke Jawa adalah terletak pada para penguasa. Dalam kaitan ini jargon religius-politik, al nasu 'ala al-dini mullukihim bahwa agama rakyat berimankan pada ajaran agama rajanya. Berarti beralihnya agama raja ke Islam mempengaruhi rakyatnya untuk masuk Islam sebagai agamanya, walaupun sebagian besar hanya mengucapkan kalimat syahadat dan belum sadar untuk melaksanakan kewajiban sholat dan ajaran Islam lainnya. Sunan kalijaga menggunakan kesenian Wayang kulit ini sebagai media dakwahnya dengan beberapa pertimbangan antara lain: 1) pertunjukan wayang kulit telah dikenal dan menjadi bagian dari masyarakat Jawa. Sebelum Islam datang dan berkembang di Jawa, masyarakat Jawa telah lama menggemari kesenian, baik seni pertunjukan wayang dengan gamelan maupun seni tarik suara. Sunan Kalijaga mengetahui rakyat dari kerajaan Majapahit masih lekat sekali pada kesenian dan kebudayaan, diantaranya masih gemar kepada gamelan dan keramaiankeramaian yang bersifat Syiwa-Budha: 2) didalam kitab Tantu Paggelaran yang merupakan karya akhir zaman akhir Majapahit menguraikan bagaimana terhormat dan dan dijunjung tinggi seorang dalang. Hal ini karena pada zaman itu posisi dalang sebagai seorang pendeta sehingga dihormati dan dipatuhi oleh masyarakat. Wayang yang terbuat dari kulit yang diukir merupakan permainan sakral yang dibawakan oleh para dewa untuk menyampaikan ajaran kedunia.

\section{Pengaruh Ajaran Islam dalam pertunjukan Wayang}

Masuknya wayang ke Jawa tidak saja memberikan pengaruh pada bidang agama tetapi juga dalam bidang kebudayaan yang adiluhung yaitu wayang kulit. Ketika kerajaan Majapahit mengalami keruntuhan, semua perlengkapan upacara kerajaan dibawa ke Demak termasuk wayang dan alat gamelan yang merupakan seni budaya istana yang sudah berkembang pada zaman Hindu-Budha. Atas perintah Raden Patah Walisongo meyempurnakan bentuk wayang dan membuat lakon carangan yang didalamnya dimasukan unsur aqidah, ibadah dan akhlaq menurut ajaran Iskam. Sunan Kalijaga memasukan unsur pendidikan Moral,ketuhanan dan hidup bermasyarakat.

Dengan masuknya Islam ke Jawa maka berubahlah bentuk Wayang yang ada sehingga hal ini mempengaruhi cerita yang akan dibawakan,dengan berubahnya bentuk ini dan semakin terperincinya cerita yang dibawakan dalam wayang. Kerana dalam ajaran Islam terdapat adanya larangan 
penggambaran yang menyerupai bentuk manusia. Fungsi wayang selain sebagai media hiburan juga sebagai sarana politis dalam menyebarankan Islam ditanah Jawa oleh Walisongo. Bentuk wayang juga disempurnakan lagi dan ditambah jumlahnya sehingga dapat dipergunakan untuk memainkan cerita.

\section{Menciptakan lakon carangan}

Sunan Kalijaga menciptakan menciptakan lakon-lakon baru berkenaan dengan menyelenggarakan pergelaran-pergelaran wayang dengan upah baginy( sebagai dalang) berupa kalimat syahadat. Untuk memudahkan masyarakat awam dalam menerima dan memahami agama Islam, Sunan Kalijaga juga memasukan rukun Islam kedalam tokoh pandawa lima.

Rukun Islam kesatu adalah kalimat syahadat atau syahadatain yang dijelmakan dalam tokoh Puntadewa sebagai anak sulung dari Pandawa. Dalam cerita wayang sifat-sifat Puntadewa sebagai raja yang memiliki sikap berbudi arif bijaksana, adil dalam perbuatan dan jujur dalam setiap perkataan. Puntadewa ini merupakan pengejawentahan dari kalimat syhadat yang selama mengilhami kearifan dan keadilan. Puntadewa memimpin empat orang saudaranya dalam suka dan duka dan penuh rasa kasih sayang. Demikian pula dengan rukun Islam yang kedua,ketiga,keempat dan kelima. Namun jika tidak menjalankan rukun Islam yang pertama maka yang lain akan sia-sia

Rukun Islam kedua adalah Sholat yang dipersonifikasikan dalam tokoh Bima atau Werkudara. Dia dikenal sebagai penegak pandawa kerana dia jarang sekali duduk bahkan tidur saja sambil berdiri hal ini seperti halnya sholat yang setiap saat harus dikerjakan tanpa menghalangi apun karena sholat merupakan tiang agama bagi umat Islam.

Rukun Islam ketiga adalah puasa dipersonifikasikan dengan Janak dalam pewayangan Arjuna disebut lelananging jagat atau pria pilihan. Nama arjuna diambil dari kata jun yang berarti jembangan. Benda ini merupakan simbol yang jernih. Kejernihan Arjuna memancar dari wajah dan tubuhnya. Arjuna juga merupakan pecinta seni keindahan, perasaannya yang sangat halus dan hangat. Banyak wanita yang suka dan tergila-gila kepadanya.karena kehalusan budi pekertinya, arjuna sulit mengatakan tidak sehingga ada kesan seolah-olah lemah padahal dia tidak ingin menyakiti hati orang lain. Jadi bagi orang yang suka berpuasa jiwanya menjadi kuat menghadapi segala cobaan.

Rukun Islam keempat dan kelima adalah zakat dan haji yang dipersonifikasikan Nakula-Sadewa. Pandawa bukanlah pandawa jika tidak ada yang kembar meskipun mereka dilahirkan dari ibu yang berbeda. Mereka juga mempunyai kepribadian yang bagus rajin bekerja dan berpakaian bagus. Ibarat orang yang senang mengeluarkan Zakat dan menunaikan ibadah Haji adalah yang giat bekerja, sehingga menjadi kaya dan dermawan, mampu berpakaian cukup sandang dan pangan, maka harta itu berfungsi sosial harus dizakati supaya suci lahir dan batin. 


\section{Nilai Filosofis Wayang Kulit}

Filsafat menurut masyarakat Jawa ialah usaha manusia untuk memperoleh pengertian dan pengetahuan tentang hidup menyeluruh dengan mempergunakan kemampuan rasio ditambah indera batin (cipta-rasa). Maka berfilsafat maka cinta kesempurnaan, (ngudi kasempurnan, ngudi kawicaksanaan) dan bukan semata-mata cinta kearifan. Jika orang jawa menyebut bahwa wayang mengandung filsafat yang dalam, dunia wayang memberi peluang bagi orang Jawa untuk melakukan suatu pengkajian filsafi dan mistis sekaligus. Dunia pewayangan kaya sekali dengan lambang atau pasemon, hampir seluruh eksistensi wayang itu sendiri adalah pasemon.

Pergelaran Wayang kulit senantiasa terdiri dari beberapa bagian atau adegan yang saling bertalian antara satu dengan yang lain. Tiap-tiap bagian melambangkan fase atau tingkat tertentu dari kehidupan manusia. Bagianbagian tersebut antara lain:

1. Jejer (adegan pertama), melambangkan kelahiran bayi dari kandungan ibu diatas dunia serta perkembangan masa kanak-kanak sampai meningkat hingga dewasa

2.Perang gagal, melambangkan perjuangan manusia muda untuk melepaskan diri dari kesulitan serta penghalang dalam perkembangan hidupnya

3.Perang kembang, melambangkan peperangan antara baik dengan buruk yang akhirnya dimenangkan oleh pihak yang baik. Perang kembang berlangsung setelah lepas tengah malam. Artinya filosofisnya yaitu setelah orang mengakhiri masa muda sampailah masa dewasa.

4.Perangbrubuh, melambangkan kehidupan manusia yang akhirnya mencapai kebahagiaan hidup hingga penemuan jati diri.

5. Tancep kayon, melambangkan berakhirnya kehidupan artinya pada akhirnya manusia mati, kembali kealam baka menghadap Tuhan Yang Maha Kuasa

\section{Fungsi dan Peranan Wayang masa Sekarang}

Rubrik wayang itu identik dengan budaya jawa. Bahkan di era sekarang penggunaan tokoh wayang sering dijadikan sarana refleksi dan keteladanan masyarakat.hal ini sering ditampilkan dalam surat kabar solopos.

Sebagai bentuk kesenian tradisional merupakan produk lokal bahkan selalu menarik dalam media lokalpun sperti televisi orang dari luarpun sudah mengganggap bahwa menanggap wayang sebagai status sosial maka orang dari kalangan luar jawa sudah menganggap wayang sebagai suatu kebudayaan yang unggul dan memiliki nilai-nilai filosofis yang tinggi.

Wayang dalam nilai-nilai budaya jawa punya jenis dan corak yang beraneka ragam salah satunya wayang purwa dan adanya berbagai modifikasi 
kontemporer dan menjadikan wayang jauh lebih menarik dan wayang dijadikan sebagai realitas budaya jawa yang kaya akan falsafah hidup yang luhur sehingga oleh media situasi dikemas dengan berbagai format yang dapat dijual ataupun memiliki daya tarik tertentu.

Seni karawitan wayang dalam pentas wayng merupakan perpaudaun antara seni suara dengan seni musik. Paduan antara seni suara dan seni musik menjadi identik. Seni karawitan ditunjukan bagaimana rumitnya para niyaga (penabuh gamelan) mengiringi jalannya cerita dengan komposisi musik yang padu, sedangkan seni sastra tergambarkan melalui dalang yang membuat narasi cerita wayang, berakting sesuai watak masing-masing wayang. Gabungan antara keseluruhannya dapat menciptakan pertunjukan wayang kulit yang dapat dinikmati berbagai kalangan masa sekarang dengan seni yang indah,rumit dan kompleks.

Dalam pementasan wayang era sekarang menggunakan media musik antara lain musik klasik dan modern:

\section{(a) Musik klasik}

Musik klasik terdiri dari seperangkat gamelan yang terdiri dari dua laras yakni laras pelog dan laras slendro. Musik gamelan lazimnya terdiri dari saron, demung, kenong, gong, rebab, kendang, gender, gambang, dan demung. Uniknya gamelan alat musik tradisional yang serba bisa. Gamelan merupakan peralatan sederhana yang dapat dipakai untuk mengiringi gendhing-gendhing atau lagu apapun.

(b) Musik modern

Pementasan wayang dewasa ini tidak hanya didukung musik kalsik yang berupa seperangkat gamelan. Seiring perkembangan zaman, pementasan sering dilengkapi dengan alat musik modern bertenaga listrik seperti keyboard. Keyboard dimanfaatkan untuk menambah pementasan misalnya efek suara dalam adegan adegan tertentu, suara angin, suara hewan dan lain-lain.

Kebudayaan dalam arti tertentu merupakan hasil karya cipta manusia yang dapat dinikmati dengan indera. Pengertian ini mencakup bermacammacam wujud, antara lain adalah penggunaan wayang purwa yang di dalamnya tentu terdapat unsur-unsur budaya daerah. Unsur-unsur budaya daerah ini tentu mengalami kontak-kontak dengan budaya asing yang ada di dalam negeri seiring dengan kemajuan teknologi di era globalisasi maka tidak dapat dipungkiri bahwa intensitas kebudayaan asing di dalam negeri semakin meningkat. Kemajuan dan pesatnya pembangunan di berbagai bidang, terlebih di bidang komunikasi memungkinkan adanya kontak-kontak yang lebih sering dengan kebudayaan asing.

Pertunjukan wayang purwa sangat berdampak positif bagi perubahan sikap dalam masyarakat. Dalam hal ini wayang merupakan bahasa simbol kehidupan yang lebih bersifat rohaniah daripada jasmaniah. Setiap penonton yang melihat pagelaran wayang yang dilihat bukan wayangnya melainkan 
masalah yang tersirat dalam tokoh pelaku dalam pewayangan itu. Hal ini sejenis dengan perumpamaan ketika orang melihat di kaca rias, orang bukan melihat tebal dan jenis kaca rias itu, melainkan melihat apa yang tersirat dalam kaca tersebut. Masalah pokok dalam pewayangan yaitu menggambarkan proses kehidupan manusia secara totalitas, sebagai pribadi, makhluk sosial maupun sebagai makhluk Tuhan. Muatan di dalam nilai-nilai wayang dalam kehidupan sehari-hari di masyarakat adalah bagaimana manusia dapat menempatkan dirinya pada tempat yang telah ditentukan oleh Tuhan dan bagaimana manusia memenuhi fungsinya serta menjalankan tugasnya berdasarkan fungsi itu. Di sisi lain, manusia mempunyai tugas-tugas sosial yang mencangkup tugas memelihara, membina, memajukan negara, bangsa dan kemanusiaan pada umumnya. Tugas-tugas seperti ini menurut istilah pewayangan yang digariskan dalam ajaran mahayu hayuning proja, mahayu hayuning bangsa dan mahayu hayuning bawana. Untuk memelihara, membina, memajukan negara, bangsa dan dunia tugas manusia utama adalah memberantas kejahatan, yang diajarkan dalam ajaran sura dira jayaningrat lebur dening pangastuti. Sebagai bentuk simbolis kehadiran wayang purwa dalam tradisi bersih desa mengandung suatu maksud di balik bentuk atau wujudnya, yaitu ekspresi penghormatan kepada Tuhan maupun roh-roh nenek moyang. Wayang purwa sebagai simbol kehidupan mengandung nilai-nilai yang berharga bagi masyarakat Jawa.

Pengetahuan dan sikap dalam pertunjukan wayang purwa pada dasarnya mencerminkan perilaku bijaksana. Kebijaksanaan hidup manusia jawa yang dimaksudkan merupakan cara ataupun saran untuk menciptakan kehidupan yang selaras dan harmonis agar tercipta kesejahteraan dunia dan akhirat. Wayang purwa secara simbolis memberikan kontribusi positif pada pembentukan sikap hidup manusia dalam upaya mencapai kehidupan yang selaras dengan lingkungan

Pada era yang sekarang pemahaman tentang wayang juga perlu dikaji melalui budaya bahwa orang yang dapat memahami wayang ialah orang yang mampu berbahasa Jawa dengan baik. Di era yang global ini fungsi dan peranan wayang sudah jauh berbeda dengan masa dulu karena pada masa sekarang Wayang Purwa digunakan sebagai media hiburan yang cukup mengasikan dan hal itu kita bisa lihat di televisi maupun media lainya seperti radio juga menyiarkan cerita wayang.

Fungsi wayang yang sesungguhnya sebagai pelestari budaya lokal khususnya Jawa untuk dijadikan budaya Nasional karena nilai-nilai yang terkandung dalam wayang sangatlah komplek. Menyangkut Agama,akhlaq dan sebagainya. Filosofi wayang sangatlah tinggi karena kita menceritakan tentang berbagai lakon carangan dan cerita aslinya. Karena perubahan jaman yang semakin modern maka cerita wayang diubah keberbagai cerita antara seperti wayang tentang kritik terhadap pemerintahan, hal ini mencerminkan bahwa penggunaan wayang selain sebagai media hiburan juga bisa berfungsi sebagai kritik sosial kepada pemerintah. Bahkan penggunaan wayang yang 
dulunya terbuat dari kulit kerbau sekarang sudah bisa diubah menggunakan kertas A4, dan menggunakan berbagai tokoh cerita yang baru

\section{PENUTUP}

Wayang dan peranannya seperti pada penggambaran diatas memberikan informasi yang sangat penting bagi kita semua, secara umum wayang memiliki peranan dan fungsi yang berbeda ketika wayang dijadikan sebagai media saluran informasi baik masa lampau maupun masa sekarang. Wayang juga memberikan informasi penting terkait dengan kehidupan estetis masyarakat masa lampau. Tidak hanya itu, wayang juga memiliki peranannya dalam hal saluran dakwah ketika perkembangan Islam di tanah Jawa dan di era sekarang wayang dijadikan sebagai saluran hiburan masyarakat secara umum dan dapat diterima oleh masyarakat secara luas karena di dalam ceritanya mengandung nilai-nilai moral kehidupan.

\section{DAFTAR PUSTAKA}

Bastomi, Suwaji. 1996. Gemar Wayang. Semarang: IKIP Semarang Press.

Kayam, Umar. 2001. Kelir Tanpa Batas. Yogyakarta:UGM.

PaEni, Muklis. 2009. Sejarah Kebudayaan Indonesia. Jakarta: PT Raja Grafindo Persada.

Puspitasari,Marina.2008. Wayang Kulit sebagai media penyebaran agama Islam. Surakarta:UNS.

Sujamto. 1992. Wayang dan Budaya Jawa. Semarang: Effhar dan Dahara Prize. 